\title{
Knowledge and Compliance in Practices in Diagnosis and Treatment of Syphilis in Maternity Hospitals in Teresina - PI, Brazil
}

\section{Conhecimento e conformidade quanto às práticas de diagnóstico e tratamento da sífilis em maternidades de Teresina - Pl, Brasil}

\author{
Raquel Rodrigues dos Santos ${ }^{1}$ Roberta Pereira Niquini ${ }^{2}$ Rosa Maria Soares Madeira Domingues ${ }^{3}$ \\ Francisco Inácio Bastos 4
}

${ }^{1}$ Hospital Geral do Promorar, Teresina, PI, Brazil

2 Instituto Federal de Educação, Ciência e Tecnologia do Rio de Janeiro

Address for correspondence Roberta Pereira Niquini, PhD, Instituto Federal de Educação, Ciência e Tecnologia do Rio de Janeiro (IFRJ) (IFRJ), Rio de Janeiro, Brazil

3 Instituto Nacional de Infectologia Evandro Chagas, Fundação Campus Realengo, Rua Carlos Wenceslau, $n^{\circ} 343$, Realengo, 21715-

Oswaldo Cruz (INI - Fiocruz), Rio de Janeiro, Brazil

${ }^{4}$ Instituto de Comunicação e Informação Científica e Tecnológica em Saúde (ICICT), Fundação Oswaldo Cruz (Fiocruz), Rio de Janeiro, Brazil

000 - Rio de Janeiro, RJ, Brazil (e-mail: roberta.niquini@ifrj.edu.br).

Rev Bras Ginecol Obstet 2017;39:453-463.

\begin{abstract}
Keywords

- syphilis

- congenital syphilis

- health personnel

- health evaluation

- maternity hospitals

Objective To assess the knowledge and compliance of health professionals regarding the diagnostic and treatment practices for syphilis in patients admitted for childbirth in public maternity hospitals in the city of Teresina, in the state of Piauí, Northeastern Brazil.

Methods A cross-sectional study was performed in 2015 with obstetricians and nurses working in the public maternity hospitals in Teresina $(n=159)$ using a selfadministered questionnaire, with $5 \%$ of losses and $10 \%$ of refusals. The study used 21 evaluation criteria: 13 of them were related to knowledge ( 5 on serological tests and 8 on treatment adequacy); 8 were related to practices ( 3 on diagnosis, 4 on treatment, and 1 on post-test counseling). The knowledge of and compliance to the practices was estimated as the proportion of health professionals' answers that were in agreement with Brazilian Ministry of Health protocols.

Results The obstetricians were in agreement with two criteria concerning the knowledge of serological tests, one for diagnostic practices, and one for treatment practice. Among nurses, no single match between actual procedures and guidelines was observed.

Conclusions Low compliance with the protocols results in missed opportunities for the diagnosis and treatment of pregnant and postpartum women and their partners. Strategies for training and integrating the various professional groups, improved data recording on prenatal cards, and greater accountability of the hospital team in managing the women's partners are needed to overcome the barriers identified in the study and to interrupt the syphilis transmission chain.
\end{abstract}

received

December 1, 2016

accepted

June 23, 2017

published online

August 23, 2017
DOI https://doi.org/

10.1055/s-0037-1606245. ISSN 0100-7203.
Copyright (e 2017 by Thieme Revinter

Publicações Ltda, Rio de Janeiro, Brazil
License terms

(ㄷ) (i) $\ominus$ (\$) 


\section{Resumo}

\author{
Palavras-chave \\ - sífilis \\ - sífilis congênita \\ - pessoal de saúde \\ - avaliação em \\ saúde \\ - maternidades
}

Objetivo Avaliar o conhecimento e a conformidade em práticas de diagnóstico e tratamento no manejo da sífilis por ocasião da admissão para o parto entre os profissionais de saúde atuantes nas maternidades públicas de Teresina, Piauí, na Região Nordeste do Brasil.

Métodos Realizou-se, em 2015, um estudo transversal com a população de médicos obstetras e enfermeiros atuantes nas maternidades públicas de Teresina $(n=159)$ por meio de formulários autoaplicáveis, tendo sido registradas $5 \%$ de perdas e $10 \%$ de recusas. Foram utilizados 21 critérios de avaliação: 13 relacionados ao conhecimento ( 5 sobre exames sorológicos e 8 sobre adequação do tratamento) e 8 relacionados às práticas ( 3 sobre diagnóstico, 4 sobre tratamento, e 1 sobre aconselhamento pósteste). A conformidade dos conhecimentos e práticas foi estimada como a proporção de respostas dos profissionais em concordância com os protocolos do Ministério da Saúde brasileiro.

Resultados Foi observada concordância em dois critérios de conhecimento sobre exames sorológicos, um relacionado às práticas diagnósticas, e um de prática de tratamento, entre os médicos. Entre os enfermeiros, nenhum critério avaliado apresentou concordância com os critérios padrão.

Conclusões O perfil observado de baixa conformidade quanto aos critérios avaliados resulta em oportunidades perdidas de diagnóstico e tratamento das gestantes/ puérperas e de seus parceiros. Estratégias de capacitação e integração das diversas categorias profissionais, melhoria nos registros no cartão de pré-natal e maior responsabilização da equipe hospitalar no manejo do parceiro são necessárias para superar as barreiras encontradas e interromper a cadeia de transmissão da doença.

\section{Introduction}

The most recent available global estimates of syphilis in pregnancy, obtained from World Health Organization (WHO) databases, indicate that $\sim 1.4$ million pregnant women presented active syphilis infection worldwide in 2008, distributed across Asia (44.3\%), Africa (39.3\%), the Americas (7.8\%), the Pacific (4.0\%), the Mediterranean (3.0\%), and Europe (1.6\%). In the absence of adequate diagnosis and treatment, an estimated 710,000 pregnancies evolve to adverse outcomes associated with the infection, including stillbirth, early fetal deaths, neonatal deaths, prematurity, low birth weight, and infected newborns, ${ }^{1}$ with an extremely high burden of disease. ${ }^{2}$

The elimination of congenital syphilis (CS) is a top public health priority. The goal is to reduce the incidence of congenital syphilis to below 0.5 cases per 1,000 live births. ${ }^{3-5}$ In Brazil, 19,228 new cases of CS were reported to the Information System on Notifiable Diseases (Sinan, in the Portuguese acronym) in 2015, with an incidence rate of 6.5 per 1,000 live births, which 13 times higher than the goal of elimination. ${ }^{6}$

The principal strategy for the control of CS is the identification and treatment of pregnant women with syphilis infection during prenatal care. However, worldwide, some two thirds of the adverse outcomes associated with syphilis in pregnancy occur in women who received prenatal care but were not tested and/or treated for syphilis. ${ }^{1}$ Therefore, in order to achieve the goal of eliminating CS, the WHO established three process goals related to the care provided to pregnant women: offer prenatal care, test for diagnosis of syphilis, and treat the disease during pregnancy, with coverage of at least $95 \%{ }^{5}$

The Brazilian Ministry of Health $(\mathrm{MoH})$ also recommends serological testing at the first prenatal visit, with an additional test at the beginning of the third trimester of pregnancy and another test upon hospital admission for childbirth or curettage. This additional testing aims to identify cases or inadequate treatments during pregnancy, ${ }^{7}$ and provides new opportunities for the diagnosis and treatment of the mothers, their partners and newborns at the time of childbirth. ${ }^{8}$

In Brazil, of all cases of CS registered in 2015, 78.4\% of the pregnant women had received prenatal care, but only $51.4 \%$ underwent a syphilis diagnostic test during pregnancy, only $34.6 \%$ underwent it during admission for childbirth or curettage, only $8.9 \%$ underwent it after that period, and $5.1 \%$ with diagnostic period ignored. From those pregnant women who received prenatal care, $56.5 \%$ received inadequate treatment, and $27.3 \%$ were untreated, whereas the majority of their partners were untreated $(62.3 \%)$ or with ignored registered information about treatment (23.8\%), ${ }^{6}$ thus revealing serious flaws in this care.

An even worse situation was observed in some states of the Northeast of Brazil (the least economically developed region of the country). Piauí is one of the Northeastern states, with a CS rate of 7.8 per 1,000 live births in $2015,{ }^{6}$ and its capital, Teresina, is the state's largest city, with 800,000 inhabitants, and a CS rate of 15.3 per 1,000 live births. In this city, of all cases of CS registered in 2015, 43.2\% underwent a syphilis diagnostic 
test during admission for childbirth or curettage, and $10.3 \%$, after that period; $76.5 \%$ of them were inadequately treated, $21.1 \%$ had absence of treatment/ignored information (21.1\%), and $77.5 \%$ of their partners were not treated. ${ }^{9}$

Given the gap between Brazil's epidemiological situation and the goal of eliminating congenital syphilis, plus the need to intervene to avoid missing the opportunity to diagnose and treat women with syphilis and their newborns, this study aims to assess the knowledge of and compliance to the practices in the diagnosis and treatment of syphilis upon the admission of pregnant women for childbirth by the health professionals working in the public maternity hospitals in Teresina, Piauí, in relation to Brazilian $\mathrm{MoH}$ protocols.

\section{Methods}

A cross-sectional study was conducted from February 1st to March 31st, 2015, with the obstetricians and nurses working in the public maternity hospitals in Teresina, Piauí (three municipal and one state hospital), in operation during the study period. The sample excluded professionals that were working exclusively in management, administrative, outpatient, and materials and sterilization services or in the maternal intensive care unit (ICU).

The health professionals were contacted by the principal investigator during their ward duty at the maternity hospitals. After an invitation to participate in the study, they received a self-applied questionnaire with multiple-choice questions, to be returned in a sealed, unidentified envelope at the end of their shift or on a date and time suggested by the participant.

Refusals were defined as professionals who stated that they declined to participate, returned the questionnaire blank, or failed to return the questionnaire after scheduling three attempts for this purpose, while losses were defined as professionals that were not contacted because they were on maternity or sick leave or vacation during the study period. A field spreadsheet was used to control the return of the questionnaires, in which there was no key field connected to the questionnaires, which enabled the calculation of the response rate while safeguarding the participants' anonymity.

The professionals' profile was characterized through a descriptive analysis of their demographic and training characteristics and careers, with a point estimate of proportions and respective $95 \%$ confidence intervals (95\%CIs).

In order to assess the health professionals' knowledge and practices in the management of syphilis in patients admitted for childbirth, we used the normative evaluation as the theoretical reference, ${ }^{10}$ according to the guidelines in the $\mathrm{MoH}$ protocols, as of the study's starting date. ${ }^{7,11}$ The guidelines were summarized in 21 evaluation criteria: 13 of them were related to knowledge ( 5 on serological tests and 8 on treatment adequacy based on hypothetical clinical cases); 8 were related to practices ( 3 on diagnosis, 4 on treatment, and 1 on post-test counseling). Agreement was assessed by the group of researchers considering the core of contents, which were expressed in multiple choice questions comparing and contrasting the professionals' answers about their knowledge and practices in the diagnosis and treatment of syphilis vis-à-vis the standard procedures as stated in the manuals.

Compliance with the evaluation criteria was estimated as the proportion of the health professionals' answers that agreed with the $\mathrm{MoH}$ protocols, with the respective $95 \% \mathrm{CI}$. The criteria were considered compliant when the interval estimate included $95 \%$ compliance or greater, according to the standard adopted by the WHO for diagnostic and therapeutic goals for syphilis in pregnancy. ${ }^{5}$ The questionnaires were keyed into the EpiData (EpiData Association, Odense, Denmark) software, version 3.1, with duplicate keying-in of $15 \%$ of the questionnaires and correction of errors as identified. Statistical analyses were performed using the Statistical Package for the Social Sciences (SPSS, IBM Corp., Armonk, NY, US) software, version 20.

The research project was approved by the Institutional Review Boards of our institutions (CAAE case review no. 861.845). In order to ensure the research subjects' anonymity, rather than an informed consent form, a letter of invitation that contained information on the study and relevant information on the investigators, the same procedure adopted in a previous study, was sent. ${ }^{12}$ Thus, filling out and returning the questionnaire were considered expressions of consent by the health professional to participate in the study.

\section{Results}

A total of 237 obstetricians and nurses working in the public maternity hospitals in Teresina were considered eligible, of whom 13 (5\%) were on vacation or maternity or sick leave, and were thus not invited to participate. Of the 224 health professionals invited to participate in the study, 22 (10\%) refused. Of the questionnaires received, 59 were filled out by obstetricians, 100 by nurses who worked with women admitted for childbirth, and 43 by nurses who worked only with the newborns. The latter group was not included in the present study, as our aim was to evaluate the knowledge and practices related to women's care.

Of the 159 professionals that participated in the study, the majority were women (67\%), under 40 years of age (65\%), who had graduated from higher education less than 10 years before the present study (53\%), with less than 10 years of experience working in maternity hospitals (71\%), and with job stability in the public service (74\%). Among the nurses, there was a statistically higher percentage of women, younger individuals (under 30 years of age), and of respondents with less time since graduation and fewer years of experience working in maternity hospitals when compared with the obstetricians (-Table $\mathbf{1}$ ).

An analysis of the participants' complementary training showed that $88 \%$ of them had attended some kind of graduate course, and $54 \%$ of these had a specialization or residency in maternal and child health; the percentages were statistically lower for nurses in both cases.

Total 39\% of the professionals stated that they had participated in some training on syphilis management, of whom more than $2 / 3$ (69\%) had received their most recent training 1 to 5 years before the study. Nearly $2 / 3$ (64\%) of the subjects 
Table 1 Demographic, training, and work characteristics of health professionals in public maternity hospitals. Teresina, state of Piauí, Brazil, $2015(n=159)$

\begin{tabular}{|c|c|c|c|c|c|c|}
\hline \multirow[b]{2}{*}{ Variables } & \multicolumn{2}{|c|}{$\begin{array}{l}\text { Obstetricians } \\
(n=59)\end{array}$} & \multicolumn{2}{|c|}{$\begin{array}{l}\text { Nurses } \\
(n=100)\end{array}$} & \multicolumn{2}{|c|}{$\begin{array}{l}\text { Total } \\
(n=159)\end{array}$} \\
\hline & $\mathrm{n}$ & $\%(95 \% \mathrm{Cl})^{*}$ & $\mathrm{n}$ & $\%(95 \% \mathrm{Cl})^{*}$ & $\mathrm{n}$ & $\%(95 \% \mathrm{Cl})^{*}$ \\
\hline \multicolumn{7}{|l|}{ Sex } \\
\hline Female & 20 & $34(22.4-47.5)$ & 86 & $86(77.2-91.8)$ & 106 & $67(58.7-73.8)$ \\
\hline Male & 39 & 66 (52.5-77.6) & 14 & $14(8.1-22.7)$ & 53 & $33(26.2-41.3)$ \\
\hline \multicolumn{7}{|l|}{ Age group (years) } \\
\hline$<30$ & 4 & $7(2.2-17.3)$ & 39 & $39(29.5-49.3)$ & 43 & $27(20.4-34.8)$ \\
\hline $30-39$ & 25 & $42(29.8-55.9)$ & 35 & $35(25.9-45.2)$ & 60 & $38(30.3-45.8)$ \\
\hline $40-49$ & 13 & $22(12.7-35.0)$ & 14 & $14(8.1-22.7)$ & 27 & $17(11.7-23.9)$ \\
\hline$\geq 50$ & 16 & $27(16.7-40.5)$ & 9 & $9(4.4-16.3)$ & 25 & $16(10.6-22.5)$ \\
\hline \multicolumn{7}{|l|}{ Time since graduation } \\
\hline$<10$ years & 15 & $25(15.4-38.7)$ & 70 & 70 (59.9-78.5) & 85 & $53(45.4-61.3)$ \\
\hline$\geq 10$ years & 43 & $73(59.5-83.2)$ & 29 & $29(20.6-39.1)$ & 72 & $45(37.4-53.3)$ \\
\hline \multicolumn{7}{|c|}{ Time working in the maternity hospital } \\
\hline$<10$ years & 26 & $44(31.4-57.5)$ & 87 & $87(78.4-92.6)$ & 113 & $71(63.3-77.8)$ \\
\hline$\geq 10$ years & 32 & $54(40.8-67.1)$ & 9 & $9(4.4-16.8)$ & 41 & $26(19.3-33.4)$ \\
\hline \multicolumn{7}{|c|}{ Employment relationship in maternity hospital } \\
\hline Stable/public servant & 49 & $83(70.6-91.1)$ & 69 & $69(58.8-77.7)$ & 118 & $74(66.6-80.7)$ \\
\hline Temporary & 10 & $17(8.8-29.4)$ & 30 & $30(21.4-40.1)$ & 40 & $25(18.8-32.8)$ \\
\hline \multicolumn{7}{|l|}{ Graduate training } \\
\hline Yes & 59 & $100(92.4-100.0)$ & 81 & $81(71.7-87.9)$ & 140 & $88(81.7-92.5)$ \\
\hline No & 0 & $0(0.0-7.6)$ & 17 & $17(10.5-26.1)$ & 17 & $11(6.5-16.8)$ \\
\hline \multicolumn{7}{|c|}{ Most recent types of graduate training } \\
\hline Specialization/residency & 53 & $90(78.5-95.8)$ & 68 & $68(57.8-76.8)$ & 121 & $76(68.6-82.3)$ \\
\hline Master’s & 2 & $3(0.6-12.7)$ & 13 & $13(7.4-21.6)$ & 15 & $9(5.5-15.3)$ \\
\hline $\mathrm{PhD}$ & 3 & $5(1.3-15.0)$ & 0 & $0(0.0-4.6)$ & 3 & $2(0.5-5.9)$ \\
\hline Other & 1 & $2(0.1-10.3)$ & 0 & $0(0.0-4.6)$ & 1 & $1(0.0-4.0)$ \\
\hline \multicolumn{7}{|c|}{ Most recent type of specialization/residency $\left.{ }^{* *}{ }^{* * *}\right)$} \\
\hline Maternal and child health & 47 & $89(76.3-95.3)$ & 18 & $26(16.8-38.8)$ & 65 & $54(44.4-62.7)$ \\
\hline ICU/urgency and emergency & 1 & $2(0.1-11.4)$ & 18 & $26(16.8-38.8)$ & 19 & $16(10.0-23.7)$ \\
\hline Family health / public health & 0 & $0(0.0-8.4)$ & 10 & $15(7.6-25.8)$ & 10 & $8(4.2-15.0)$ \\
\hline Other & 6 & $11(4.7-23.7)$ & 19 & $28(18.1-40.3)$ & 25 & $21(14.0-29.2)$ \\
\hline \multicolumn{7}{|c|}{ Participation in training on syphilis } \\
\hline Yes & 22 & $37(25.3-50.9)$ & 40 & $40(30.5-50.3)$ & 62 & $39(31.5-47.1)$ \\
\hline No & 36 & $61(47.4-73.2)$ & 57 & $57(46.7-66.7)$ & 93 & $58(50.4-66.2)$ \\
\hline \multicolumn{7}{|l|}{ Most recent training ${ }^{* * *}$} \\
\hline$<1$ year & 0 & $0(0.0-18.5)$ & 3 & $8(1.9-21.5)$ & 3 & $5(1.2-14.4)$ \\
\hline 1 to 5 years & 13 & $59(36.7-78.5)$ & 30 & $75(58.5-86.7)$ & 43 & $69(56.2-80.1)$ \\
\hline$>5$ years & 9 & $41(21.5-63.3)$ & 6 & $15(6.2-30.5)$ & 15 & $24(14.6-37.0)$ \\
\hline \multicolumn{7}{|l|}{ Knows MoH manual } \\
\hline Yes & 31 & $52(39.2-65.5)$ & 71 & $71(60.9-79.4)$ & 102 & $64(56.1-71.5)$ \\
\hline No & 26 & $44(31.4-57.5)$ & 25 & $25(17.1-34.8)$ & 51 & $32(25.0-40.0)$ \\
\hline
\end{tabular}


Table 1 (Continued)

\begin{tabular}{|c|c|c|c|c|c|c|}
\hline \multirow{2}{*}{ Variables } & \multicolumn{2}{|c|}{$\begin{array}{l}\text { Obstetricians } \\
(n=59)\end{array}$} & \multicolumn{2}{|c|}{$\begin{array}{l}\text { Nurses } \\
(n=100)\end{array}$} & \multicolumn{2}{|c|}{$\begin{array}{l}\text { Total } \\
(n=159)\end{array}$} \\
\hline & $n$ & $\%(95 \% \mathrm{Cl})^{*}$ & $\mathrm{n}$ & $\%(95 \% \mathrm{Cl})^{*}$ & $\mathrm{n}$ & $\%(95 \% \mathrm{Cl})^{*}$ \\
\hline \multicolumn{7}{|c|}{ Last time consulting the $\mathrm{MoH}$ manual ${ }^{* * *}$} \\
\hline$<1$ year & 4 & $13(4.2-30.8)$ & 12 & $17(9.4-28.0)$ & 16 & $16(9.5-24.5)$ \\
\hline 1 to 5 years & 23 & $74(55.1-87.4)$ & 48 & $68(55.3-77.9)$ & 71 & $70(59.6-78.1)$ \\
\hline$>5$ years & 2 & $6(1.1-22.8)$ & 9 & $13(6.3-23.2)$ & 11 & $11(5.8-18.9)$ \\
\hline \multicolumn{7}{|c|}{ Read MoH manual *** } \\
\hline Yes, entirely & 13 & $42(25.1-60.7)$ & 11 & $16(8.3-26.4)$ & 24 & $23(15.9-33.1)$ \\
\hline Yes, partially & 16 & $52(33.4-69.4)$ & 57 & $80(68.8-88.4)$ & 73 & $72(61.6-79.8)$ \\
\hline No & 2 & $6(1.1-22.8)$ & 3 & $4(1.1-12.7)$ & 5 & $5(1.8-11.6)$ \\
\hline
\end{tabular}

Abbreviations: $95 \% \mathrm{Cl}$, 95\% confidence interval; ICU, intensive care unit; $\mathrm{MoH}$, Ministry of Health.

Notes: *Proportions of the total obstetricians (59) and nurses (100): the totals for each variable differ due to the small number of "missing" cases;

${ }^{* *}$ multiple-choice question; ${ }^{* * *}$ question answered by participants that answered yes to the previous question.

reported knowing the MoH manual on prevention of congenital syphilis, and $70 \%$ of them had last consulted it between 1 and 5 years before the study. The manual had been read in its entirety by $23 \%$ of the professionals.

In relation to the knowledge of serological tests ( - Table 2 ), $79 \%$ of the obstetricians and nurses identified the Venereal Disease Research Laboratory (VDRL) test as a non-treponemal test, $77 \%$ identified the fluorescent treponemal antibodyabsorption (FTA-Abs) test and the Treponema pallidum hemagglutination assay (TPHA) as treponemal tests, and 50\% identified the rapid syphilis test as a treponemal test. The obstetricians showed higher agreement rates for the VDRL and FTA-Abs tests and the TPHA compared with the nurses.

Six percent of the professionals correctly identified the VDRL test's relevant characteristics for the clinical management in pregnancy, while the lowest percentage of correct answers was associated with the fact that this test is also considered qualitative (32\%). About $1 / 3$ of the professionals (29\%) have correctly indicated the characteristics of the treponemal tests, while $31 \%$ have erroneously stated that treponemal tests become "non-reactive" after adequate treatment, and $28 \%$ stated that they can be used to control the cure.

Agreement rates about the knowledge of the treatment of syphilis during pregnancy varied from $21 \%$ (95\%Cl: $14.9-28.0 \%)$ to $76 \%$ (95\%CI: 68.6-82.3\%) (- Table 3), and the lowest proportion of correct answers was for the minimum time between the conclusion of the treatment and childbirth for the mother's treatment to be considered adequate. The results also showed a low proportion of adequate management of the pregnant woman in relation to penicillin allergy (32\%), in the evaluation of maternal serological titers following treatment $(41 \%)$, and in the interval between doses of penicillin benzathine (48\%) during the pregnant woman's treatment. The obstetricians showed a statistically higher agreement rate than the nurses in three clinical cases: management of a pregnant woman with a low serological titer during pregnancy and report of adequate prior treatment; prescription of treatment with the correct interval between doses of penicillin benzathine; and treatment of the partner.

Of all the professionals, $74 \%$ stated that they recorded on the patient chart and/or on the hospital admission form the results of the serological tests for syphilis contained on the prenatal card and $82 \%$ of the treatments received by the woman. Ordering "syphilis serology" for all women admitted for childbirth or curettage was reported by $40 \%$ of the professionals, and was statistically more common among obstetricians (96\%; 95\%CI: 87.2-99.4\%). Among nurses, 47\% reported not ordering the tests (95\%CI: $37.0-57.2 \%$ ) and $36 \%$ reported not being allowed to order them (95\%CI: 26.8-46.3\%) (-Table 4).

Obstetricians and nurses differed significantly in relation to the correct procedure in the treatment of syphilis according to the stage of the disease. Among the obstetricians, $66 \%$ (95\%CI: 52.5-77.6\%) reported the correct treatment of primary syphilis, $52 \%$ (95\%CI: $39.2-65.5 \%$ ) reported the correct treatment of secondary syphilis, and $95 \%$ (95\%CI: $84.9-98.7 \%$ ) reported the correct treatment of syphilis of unknown duration. The majority of nurses reported not being allowed to prescribe any medicine for the pregnant women in the maternity hospital, regardless of the stage of the disease (58\%; 95\%CI: 47.7-67.7\%).

The offer of 3 recommended instructions during the posttest counseling was reported by $73 \%$ of the professionals. More than $1 / 3$ of the professionals (37\%) reported calling in the partners of the pregnant women with syphilis to the maternity hospital to order the VDRL test and prescribe treatment.

The main barriers to the adequate management of syphilis in the maternity hospitals were lack of records of the diagnosis on the prenatal card (50\%) and of the treatments received during prenatal care (65\%); the pregnant women's lack of information on the treatments performed during prenatal care (64\%); and difficulties in conversing with the women's partners (50\%) (-Table 5 ). The nurses reported statistically greater difficulty in explaining the test result to the pregnant women (41\%; 95\%CI: 31.4-51.3) when compared with the 
Table 2 Agreement of the health professionals' knowledge on laboratory tests in relation to the management of syphilis in pregnancy. Teresina, state of Piauí, Brazil, 2015

\begin{tabular}{|c|c|c|c|c|c|c|}
\hline \multirow[t]{2}{*}{ Criteria } & \multicolumn{2}{|c|}{$\begin{array}{l}\text { Obstetricians } \\
(n=59)\end{array}$} & \multicolumn{2}{|c|}{$\begin{array}{l}\text { Nurses } \\
(n=100)\end{array}$} & \multicolumn{2}{|c|}{$\begin{array}{l}\text { Total } \\
(n=159)\end{array}$} \\
\hline & $\mathbf{n}$ & $\%(95 \% \mathrm{Cl})^{*}$ & $\mathrm{~N}$ & $\%(95 \% \mathrm{Cl})^{*}$ & $\mathrm{n}$ & $\%(95 \% \mathrm{Cl})^{*}$ \\
\hline \multicolumn{7}{|l|}{ The VDRL test is non-treponemal } \\
\hline In agreement & 54 & $92(80.6-96.8)$ & 72 & $72(62.0-80.3)$ & 126 & $79(71.9-85.1)$ \\
\hline Not in agreement/not informed & 5 & $8(3.1-19.4)$ & 28 & $28(19.7-38.0)$ & 33 & $21(14.9-28.1)$ \\
\hline \multicolumn{7}{|l|}{ The rapid syphilis test is treponemal } \\
\hline In agreement & 28 & $48(34.5-60.8)$ & 51 & $51(40.9-61.0)$ & 79 & $50(41.7-57.7)$ \\
\hline Not in agreement/not informed & 31 & $52(39.2-65.5)$ & 49 & $49(38.9-59.1)$ & 80 & $50(43.3-58.3)$ \\
\hline \multicolumn{7}{|l|}{ The TPHA and FTA-Abs test are treponemal } \\
\hline In agreement & 54 & $92(80.6-96.8)$ & 69 & $69(58.8-77.7)$ & 123 & $77(69.9-83.4)$ \\
\hline Not in agreement/not informed & 5 & $8(3.1-19.4)$ & 31 & $31(22.3-41.1)$ & 36 & $23(16.5-30.1)$ \\
\hline \multicolumn{7}{|l|}{ Characteristics of the VDRL test ${ }^{* *}$} \\
\hline 1. Qualitative test & 18 & $31(19.5-44.0)$ & 33 & $33(24.1-43.2)$ & 51 & $32(25.0-40.0)$ \\
\hline 2. Can become non-reactive after adequate treatment & 41 & $70(56.0-80.4)$ & 47 & $47(37.0-57.2)$ & 88 & $55(47.3-63.1)$ \\
\hline 3. Can be used to control the cure & 46 & $78(64.9-87.3)$ & 43 & $43(33.2-53.3)$ & 89 & $56(47.9-63.8)$ \\
\hline 4. Cross-reactive with other infections & 51 & $86(74.5-93.5)$ & 28 & $28(19.7-38.0)$ & 79 & $50(41.7-57.7)$ \\
\hline 5. Does not know how to interpret the test & 0 & $0(0.0-7.6)$ & 8 & $8(3.8-15.6)$ & 8 & $5(2.3-10.0)$ \\
\hline In agreement (with items 1,2,3, and 4) & 9 & $15(7.6-27.4)$ & 1 & $1(0.1-6.2)$ & 10 & $6(3.2-11.6)$ \\
\hline Not in agreement / Not informed & 50 & $85(72.5-92.4)$ & 99 & $99(93.8-99.9)$ & 149 & $94(88.4-96.8)$ \\
\hline \multicolumn{7}{|l|}{ Characteristics of the treponemal tests** } \\
\hline 1. Qualitative tests & 39 & $66(52.5-77.6)$ & 49 & $49(38.9-59.1)$ & 88 & $55(47.3-63.1)$ \\
\hline 2. Can become non-reactive after adequate treatment & 21 & $36(23.9-49.2)$ & 29 & $29(20.6-39.1)$ & 50 & $31(24.4-39.3)$ \\
\hline 3. Can be used to control the cure & 26 & $44(31.4-57.5)$ & 19 & $19(12.1-28.3)$ & 45 & $28(21.6-36.1)$ \\
\hline 4. Cross-reactive with other infections & 7 & $12(5.3-23.5)$ & 11 & $11(5.9-19.2)$ & 18 & $11(7.0-17.5)$ \\
\hline 5. Does not know how to interpret the tests & 0 & $0(0.0-7.6)$ & 19 & $19(12.1-28.3)$ & 19 & $12(7.5-18.3)$ \\
\hline In agreement (only with item 1 ) & 20 & $34(22.4-47.5)$ & 26 & $26(18.0-35.9)$ & 46 & $29(22.2-36.7)$ \\
\hline Not in agreement/Not informed & 39 & $66(52.5-77.6)$ & 74 & $74(64.1-82.0)$ & 113 & $71(63.3-77.8)$ \\
\hline
\end{tabular}

Abbreviations: $95 \% \mathrm{Cl}$, 95\% confidence interval; FTA-Abs, fluorescent treponemal antibody-absorption; TPHA, Treponema pallidum hemagglutination assay; VDRL Venereal Disease Research Laboratory.

Notes: *Proportions of the total obstetricians (59) and nurses (100): the totals for each variable differ due to the small number of "missing" cases.

${ }^{* *}$ Multiple choice question.

obstetricians (17\%; 95\%CI: 8.8-29.4\%). For the other difficulties, there was no statistically significant evidence of differences between obstetricians and nurses (- Table 5).

\section{Discussion}

The results of the present study reveal a series of gaps in the knowledge and practices among health professionals involved in obstetric care, whose answers express approaches that fail to agree consistently with the Brazilian $\mathrm{MoH}^{7,11}$ and international protocols. ${ }^{4}$

The obstetricians agreed with two criteria pertaining to the knowledge of serological tests (the VDRL test as a non-treponemal test, and the TPHA and FTA-Abs test as treponemal tests), one criteria about diagnostic practices ("ordering syph- ilis serology for all pregnant women admitted for childbirth and curettage"), and one criteria regarding treatment practices ("treatment of syphilis of unknown duration"). Among the nurses, no criterion agreed with the protocols. These findings are worrisome, since this performance could be defined as incompatible with any concerted attempt to curb CS.

Low agreement rates were observed for laboratory tests used to diagnose syphilis, which is essential to properly manage each case. The lowest agreement rate was with the rapid syphilis test. Brazil's health care system only implemented this test in $2011,{ }^{13}$ which might explain the health professionals' lower familiarity with its use. It appears that the implementation strategies used so far have been insufficient to increase the knowledge and uptake of this test. Once applied properly, it may produce relevant benefits in terms of greater 
Table 3 Agreement of the health professionals' knowledge concerning the treatment guidelines for the management of syphilis in pregnancy. Teresina, state of Piauí, Brazil, 2015

\begin{tabular}{|c|c|c|c|c|c|c|}
\hline \multirow[t]{2}{*}{ Criteria } & \multicolumn{2}{|c|}{$\begin{array}{l}\text { Obstetricians } \\
(n=59)\end{array}$} & \multicolumn{2}{|c|}{$\begin{array}{l}\text { Nurses } \\
(n=100)\end{array}$} & \multicolumn{2}{|c|}{$\begin{array}{l}\text { Total } \\
(n=159)\end{array}$} \\
\hline & $\mathbf{n}$ & $\%(95 \% \mathrm{Cl})^{*}$ & $\mathbf{n}$ & $\%(95 \% \mathrm{Cl})^{*}$ & $\mathrm{n}$ & $\%(95 \% \mathrm{Cl})^{*}$ \\
\hline \multicolumn{7}{|c|}{ (I) Pregnant woman allergic to penicillin } \\
\hline In agreement & 24 & $41(28.3-54.2)$ & 27 & $27(18.8-37.0)$ & 51 & $32(25.0-40.0)$ \\
\hline Not in agreement/not informed & 35 & $59(45.8-71.7)$ & 73 & $73(63.0-81.2)$ & 108 & $68(60.0-75.0)$ \\
\hline \multicolumn{7}{|c|}{ (II) Low titer (1:2) at childbirth, no diagnosis, or prior treatment } \\
\hline In agreement & 44 & $75(61.3-84.6)$ & 56 & $56(45.7-65.8)$ & 100 & $63(54.8-70.3)$ \\
\hline Not in agreement/not informed & 15 & $25(15.4-38.7)$ & 44 & $44(34.2-54.3)$ & 59 & $37(29.7-45.2)$ \\
\hline \multicolumn{7}{|l|}{ (III) Treatment dose } \\
\hline In agreement & 51 & $86(74.5-93.5)$ & 70 & $70(59.9-78.5)$ & 121 & $76(68.6-82.3)$ \\
\hline Not in agreement/not informed & 8 & $14(6.4-25.5)$ & 30 & $30(21.4-40.1)$ & 38 & $24(17.6-31.4)$ \\
\hline \multicolumn{7}{|c|}{ (IV)Time elapsed between the conclusion of the treatment and delivery } \\
\hline In agreement & 11 & $19(10.1-31.3)$ & 22 & $22(14.6-31.6)$ & 33 & $21(14.9-28.0)$ \\
\hline Not in agreement/not informed & 48 & $81(68.7-89.9)$ & 78 & $78(68.4-85.4)$ & 126 & $79(71.9-85.1)$ \\
\hline \multicolumn{7}{|l|}{ (V) Serological scar } \\
\hline In agreement & 50 & $85(72.5-92.4)$ & 60 & $60(49.7-69.5)$ & 110 & $69(61.3-76.1)$ \\
\hline Not in agreement/not informed & 9 & $15(7.6-27.5)$ & 40 & $40(30.5-50.3)$ & 49 & $31(23.9-38.7)$ \\
\hline \multicolumn{7}{|c|}{ (VI) Persistent titer after treatment } \\
\hline In agreement & 24 & $41(28.3-54.2)$ & 42 & $42(32.3-52.3)$ & 66 & $41(33.8-49.6)$ \\
\hline Not in agreement/not informed & 35 & $59(45.8-71.7)$ & 58 & $58(47.7-67.7)$ & 93 & $59(50.4-66.2)$ \\
\hline \multicolumn{7}{|l|}{ (VII) Partner not treated } \\
\hline In agreement & 52 & $88(76.4-94.7)$ & 67 & $67(56.8-75.9)$ & 119 & $75(67.2-81.2)$ \\
\hline Not in agreement/not informed & 7 & $12(5.3-23.5)$ & 33 & $33(24.1-43.2)$ & 40 & $25(18.8-32.8)$ \\
\hline \multicolumn{7}{|c|}{ (VIII) Interval between treatment doses } \\
\hline In agreement & 38 & $64(50.8-76.1)$ & 39 & $39(29.5-49.3)$ & 77 & $48(40.4-56.4)$ \\
\hline Not in agreement/not informed & 21 & $36(23.9-49.2)$ & 61 & $61(50.7-70.4)$ & 82 & $52(43.6-59.5)$ \\
\hline
\end{tabular}

Abbreviation: $95 \% \mathrm{Cl}, 95 \%$ confidence interval.

Note: *Proportions of the total obstetricians (59) and nurses (100); due to the small number of "missing" cases, the values were combined as "not in agreement".

case-resolution, user-friendly execution, and gains in biosafety and patient comfort, since it does not require venous puncture. The nurses showed the greatest level of difficulty in interpreting the test result and in explaining the result to the women. Although rapid tests are probably more useful and relevant in primary care settings, health care professionals should be able to interpret test results and evaluate the adequacy of syphilis treatment during pregnancy.

All eight criteria for assessing the physicians' and nurses' knowledge about the treatment failed to agree with the $\mathrm{MoH}$ protocols. The lack of knowledge about the treatment of syphilis on the part of physicians and nurses has been reported in previous Brazilian studies focused on health professionals working in primary care. In a study conducted in the city of Recife in $2012,{ }^{14}$ more than $2 / 3$ (69\%) of the physicians and nurses knew how to treat a pregnant woman who was allergic to penicillin. In a study conducted in the city of Fortaleza in 2009, approximately half of the nurses did not know how to treat a pregnant woman with a VDRL test titer of $1: 1 .{ }^{15}$ In another study conducted in the same city and year, $51 \%$ of the nurses prescribed the correct dose for secondary syphilis, and $41 \%$ knew the correct 7-day interval between doses. $^{16}$

The treatment practices for syphilis reported by the obstetricians showed variable agreement according to the stage of the disease. The most frequent errors observed were overtreatment of the pregnant women, which by itself is not a problem for the prevention of CS. However, it does mean a waste of medicines, which is aggravated by the lack of raw material to formulate the medicine, which happened during the study, besides the fact that it is a painful and unnecessary intervention for the pregnant women.

In April 2015, the recommendation to treat secondary and recent latent syphilis was modified in Brazil, reducing the total dose of penicillin $G$ benzathine from 4,800,000 IU to $2,400,000 \mathrm{IU},{ }^{17,18}$ which is similar to the protocol adopted in 
Table 4 Agreement of the health professionals' practices concerning the management of syphilis in pregnancy. Teresina, state of Piauí, Brazil

\begin{tabular}{|c|c|c|c|c|c|c|}
\hline \multirow[t]{2}{*}{ Criteria } & \multicolumn{2}{|c|}{ Obstetricians } & \multicolumn{2}{|c|}{ Nurses } & \multicolumn{2}{|c|}{ Total } \\
\hline & $\mathrm{n}$ & $\%(95 \% \mathrm{Cl})$ & $\mathrm{n}$ & $\%(95 \% \mathrm{Cl})$ & $\mathrm{n}$ & $\%(95 \% \mathrm{Cl})$ \\
\hline \multicolumn{7}{|l|}{ Diagnostic practices } \\
\hline (A) Recording the test results** & & $\begin{array}{l}\text { Obstetricians } \\
(n=55)\end{array}$ & & $\begin{array}{l}\text { Nurses } \\
(n=68)\end{array}$ & & $\begin{array}{l}\text { Total } \\
(123)\end{array}$ \\
\hline In agreement (test results recorded) & 40 & $73(58.8-83.4)$ & 51 & $75(62.8-84.4)$ & 91 & $74(65.2-81.3)$ \\
\hline Not in agreement /not informed & 15 & $27(16.5-41.2)$ & 17 & $25(15.6-37.2)$ & 32 & $26(18.7-34.8)$ \\
\hline (B) "Syphilis serology" ordered & & $\begin{array}{l}\text { Obstetricians } \\
(n=59)\end{array}$ & & $\begin{array}{l}\text { Nurses } \\
(n=100)\end{array}$ & & $\begin{array}{l}\text { Total } \\
(159)\end{array}$ \\
\hline (1) For all women admitted for childbirth, but not for curettage & 1 & $2(0.1-10.3)$ & 4 & $4(1.3-10.5)$ & 5 & $3(1.2-7.6)$ \\
\hline (2) Only other criteria* & 0 & $0(0.0-7.6)$ & 4 & $4(1.3-10.5)$ & 4 & $2(0.8-6.7)$ \\
\hline (3) Does not order & 1 & $2(0.1-10.3)$ & 47 & $47(37.0-57.2)$ & 48 & $30(23.3-38.0)$ \\
\hline (4) Not allowed to order tests & 0 & $0(0.0-7.6)$ & 36 & $36(26.8-46.3)$ & 36 & $23(16.5-30.1)$ \\
\hline In agreement (for all women admitted for childbirth or curettage) & 57 & $96(87.2-99.4)$ & 7 & $7(3.1-14.4)$ & 64 & $40(32.6-48.3)$ \\
\hline Not in agreement / not informed & 2 & $4(0.6-12.7)$ & 93 & $93(85.6-96.9)$ & 95 & $60(51.7-67.3)$ \\
\hline \multicolumn{7}{|l|}{ (C)Management of partner } \\
\hline In agreement (treatment of partner at the maternity hospital) & 25 & $42(29.8-55.9)$ & 34 & $34(25.0-44.2)$ & 59 & $37(29.7-45.1)$ \\
\hline Other approaches & 31 & $53(39.2-65.5)$ & 47 & $47(37.1-57.2)$ & 78 & $49(41.1-57.1)$ \\
\hline No management of partner or not informed & 3 & $5(1.3-15.1)$ & 19 & $19(12.1-28.3)$ & 22 & $14(9.1-20.4)$ \\
\hline \multicolumn{7}{|l|}{ Treatment practices } \\
\hline (A)Recording the treatments performed ${ }^{* *}$ & & $\begin{array}{l}\text { Obstetricians } \\
(n=55)\end{array}$ & & $\begin{array}{l}\text { Nurses } \\
(n=68)\end{array}$ & & $\begin{array}{l}\text { Total } \\
(123)\end{array}$ \\
\hline In agreement & 46 & $84(70.7-91.8)$ & 55 & $81(69.2-89.0)$ & 101 & $82(73.9-88.2)$ \\
\hline Not in agreement & 9 & $16(8.2-29.3)$ & 13 & $19(10.9-30.8)$ & 22 & $18(11.8-26.0)$ \\
\hline (B)Treatment of primary syphilis & & $\begin{array}{l}\text { Obstetricians } \\
(n=59)\end{array}$ & & $\begin{array}{l}\text { Nurses } \\
(n=100)\end{array}$ & & $\begin{array}{l}\text { Total } \\
(159)\end{array}$ \\
\hline Not allowed to prescribe & 0 & $0(0.0-7.6)$ & 58 & $58(47.7-67.7)$ & 58 & $36(29.1-44.5)$ \\
\hline In agreement (Penicillin G Benzathine 2,400,000 IU) & 39 & $66(52.5-77.6)$ & 29 & $29(20.6-39.1)$ & 68 & $43(35.0-50.8)$ \\
\hline Does not know how to treat/not informed & 20 & $34(22.4-47.5)$ & 13 & $13(7.4-21.6)$ & 33 & $21(14.9-28.0)$ \\
\hline \multicolumn{7}{|l|}{ (C)Treatment of secondary syphilis } \\
\hline Not allowed to prescribe & 0 & $0(0.0-7.6)$ & 58 & $58(47.7-67.7)$ & 58 & $36(29.1-34.5)$ \\
\hline In agreement (Penicillin G Benzathine 4,800,000 IU) & 31 & $52(39.2-65.5)$ & 26 & $26(18.0-35.9)$ & 57 & $36(28.5-43.9)$ \\
\hline Does not know how to treat/not informed & 28 & $48(34.5-60.8)$ & 16 & $16(9.7-25.0)$ & 44 & $28(21.0-35.4)$ \\
\hline \multicolumn{7}{|l|}{ (D)Treatment of syphilis of unknown duration } \\
\hline Not allowed to prescribe & 0 & $0(0.0-7.6)$ & 58 & $58(47.7-67.7)$ & 58 & $37(29.1-34.5)$ \\
\hline In agreement (Penicillin G Benzathine 7,200,000 IU) & 56 & $95(84.9-98.7)$ & 32 & $32(23.2-42.2)$ & 88 & $55(47.3-63.2)$ \\
\hline Does not know how to treat/not informed & 3 & $5(1.3-15.0)$ & 10 & $10(5.2-18.0)$ & 13 & $8(4.6-13.9)$ \\
\hline \multicolumn{7}{|l|}{ Post-test counseling } \\
\hline $\begin{array}{l}\text { (1) Always provides orientation on the risks of the disease for the } \\
\text { pregnant woman with diagnosis of syphilis and her child }\end{array}$ & 55 & $93(82.7-97.8)$ & 81 & $81(71.7-87.9)$ & 136 & $86(78.9-90.4)$ \\
\hline $\begin{array}{l}\text { (2) Always provides orientation on the importance of the } \\
\text { partner's treatment to avoid reinfection }\end{array}$ & 57 & $97(87.2-99.4)$ & 90 & $91(82.0-94.8)$ & 147 & $92(86.9-95.9)$ \\
\hline $\begin{array}{l}\text { (3) Always provides orientation on the importance of } \\
\text { condom use to avoid reinfection }\end{array}$ & 48 & $81(68.7-89.9)$ & 81 & $81(71.7-87.9)$ & 129 & $81(74.0-86.7)$ \\
\hline In agreement (with items 1, 2, and 3) & 46 & $78(64.9-87.3)$ & 70 & $70(59.9-78.5)$ & 116 & $73(65.2-80.0)$ \\
\hline Not in agreement /not informed & 13 & $22(12.7-35.1)$ & 30 & $30(21.4-40.1)$ & 43 & $27(20.4-34.8)$ \\
\hline
\end{tabular}

Abbreviation: $95 \% \mathrm{Cl}, 95 \%$ confidence interval.

Notes: * Only for pregnant women without tests recorded on the prenatal card or who did not receive prenatal care; for all pregnant women with history of syphilis during pregnancy or for all pregnant women with lifetime history of syphilis; ${ }^{* *}$ question only answered by health professionals in charge of women's hospitalization before delivery. 
Table 5 Barriers reported by health professionals to the management of syphilis in the maternity hospital. Teresina, state of Piauí, Brazil, $2015(n=243)$

\begin{tabular}{|c|c|c|c|c|c|c|}
\hline \multirow[t]{2}{*}{ Barriers } & \multicolumn{2}{|c|}{$\begin{array}{l}\text { Obstetricians } \\
(n=59)\end{array}$} & \multicolumn{2}{|c|}{$\begin{array}{l}\text { Nurses } \\
(n=100)\end{array}$} & \multicolumn{2}{|c|}{$\begin{array}{l}\text { Total } \\
(n=159)\end{array}$} \\
\hline & $\mathrm{n}$ & $\%(95 \% \mathrm{Cl})$ & $\mathrm{n}$ & $\%(95 \% \mathrm{Cl})$ & $\mathrm{n}$ & $\%(95 \% \mathrm{Cl})$ \\
\hline (1) No record of the diagnosis on the prenatal card & 33 & $56(42.5-68.6)$ & 47 & $47(37.0-57.2)$ & 80 & $50(42.3-58.3)$ \\
\hline (2) No record of the treatments on the prenatal card & 44 & $75(61.3-84.6)$ & 60 & $60(49.7-69.5)$ & 104 & $65(57.4-72.6)$ \\
\hline $\begin{array}{l}\text { (3) Women's lack of information on treatments } \\
\text { received during prenatal care }\end{array}$ & 42 & $71(57.7-81.9)$ & 59 & $59(48.7-68.6)$ & 101 & $64(55.5-70.9)$ \\
\hline $\begin{array}{l}\text { (4) Other health professionals in the maternity hospital do not } \\
\text { record relevant information on syphilis on the patient's chart }\end{array}$ & 17 & $29(18.1-42.2)$ & 20 & $20(12.9-29.4)$ & 37 & $23(17.1-30.7)$ \\
\hline $\begin{array}{l}\text { (5) Other health professionals in the maternity hospital } \\
\text { do not order necessary tests for diagnosis and treatment }\end{array}$ & 5 & $9(3.2-19.4)$ & 5 & $5(1.8-11.8)$ & 10 & $6(3.2-11.6)$ \\
\hline $\begin{array}{l}\text { (8) Delay in the turnaround time of the results of the } \\
\text { tests ordered in the maternity hospital }\end{array}$ & 16 & $27(16.7-40.5)$ & 16 & $16(9.7-25.0)$ & 32 & $20(14.4-27.4)$ \\
\hline (9) Difficulty in interpreting the test results & 2 & $3(0.6-12.7)$ & 11 & $11(5.9-19.2)$ & 13 & $8(4.6-13.9)$ \\
\hline $\begin{array}{l}\text { (10) Women's resistance to the waiting time in } \\
\text { the postpartum period to receive the test result }\end{array}$ & 12 & $20(11.4-33.2)$ & 18 & $18(11.3-17.2)$ & 30 & $19(13.3-26.0)$ \\
\hline (11) Lack of medicines for treatment & 2 & $3(0.6-12.7)$ & 1 & $1(0.0-6.2)$ & 3 & $2(0.5-5.8)$ \\
\hline (12)Difficulty in conversing with the women's partners & 37 & $63(49.1-74.6)$ & 42 & $42(32.3-52.3)$ & 79 & $50(41.7-57.7)$ \\
\hline $\begin{array}{l}\text { (13)Difficulty in conversing with the women about } \\
\text { the possible forms of syphilis infection }\end{array}$ & 12 & $20(11.4-33.2)$ & 29 & $29(20.6-39.1)$ & 41 & $26(19.3-33.4)$ \\
\hline $\begin{array}{l}\text { (14)Difficulty in informing the women about the } \\
\text { consequences of syphilis for her and the infant }\end{array}$ & 7 & $12(5.3-23.5)$ & 24 & $24(16.3-33.8)$ & 31 & $20(13.8-26.7)$ \\
\hline (15)Difficulty in explaining the test result to the women & 10 & $17(8.8-29.4)$ & 41 & $41(31.4-51.3)$ & 51 & $32(25.0-40.0)$ \\
\hline (16)Difficulty in orienting the women on treatment & 5 & $9(3.2-19.4)$ & 26 & $26(18.0-35.9)$ & 31 & $19(13.8-26.7)$ \\
\hline (17)Difficulty in orienting the women on condom use & 7 & $12(5.3-23.5)$ & 19 & $19(12.1-28.3)$ & 26 & $16(11.1-23.2)$ \\
\hline No difficulties & 2 & $3(0.5-12.7)$ & 7 & $7(3.1-14.4)$ & 9 & $6(2.8-10.8)$ \\
\hline Not informed & 2 & $3(0.5-12.7)$ & 4 & $4(1.3-10.5)$ & 6 & $4(1.5-8.4)$ \\
\hline
\end{tabular}

Abbreviation: $95 \% \mathrm{Cl}, 95 \%$ confidence interval.

Note: The health professionals could choose more than one answer.

other countries. Strategies aimed at reinforcing the items that remained unaltered, highlighting the changes, and avoiding overtreatment are needed to disseminate and implement this new protocol.

The current study showed limited ordering of tests and treatment prescription by the nurses, revealing their low autonomy in this context. Under Brazilian legislation (Federal Law 7.498/1986 and Resolution 195/1997 of the Federal Council of Nursing - COFEN, in the Portuguese acronym), ${ }^{19,20}$ registered nurses who are actual members of the health care team can order routine and complementary tests and prescribe medicines included in public health care protocols and in routines approved by the health care institution. Our study did not assess the causes of this low performance, but some possible explanations include fear of being held accountable for the diagnosis and prescription; the nurses' incomplete knowledge of their professional responsibilities; the feeling that this is the obstetricians' exclusive responsibility; resistance by health care service administrators and attending physicians; less time since graduation and on the job in maternity hospitals among nurses (as shown by the study's empirical data); and the high proportion of nurses without stable employment contracts in the maternity hospital, who are thus subject to greater turnover and are probably less familiar with the protocols.

Evidence from previous studies showed that the outsourcing of job positions in Brazil has been accompanied by lower wages, greater instability and job turnover, accumulation of tasks, and longer work weeks, ${ }^{21}$ which can hinder the establishment of routines and effective professional training, generating inadequate practices and increasing the risk of work accidents. ${ }^{22}$ In a 2015 publication by the Brazilian $\mathrm{MoH}$, in the city of Vitória da Conquista, in the Northeastern state of Bahia, high workforce turnover was one of the problems mentioned as a barrier to the elimination of congenital syphilis. ${ }^{23}$

Regardless of the reason, the low performance of the nurses is a limiting factor in the efforts to curb syphilis, especially in such a strikingly heterogeneous country as Brazil, where regions and social strata display profoundly diverse realities in the availability of human resources and infrastructure. $^{24}$

In the current study, fewer than half of the health professionals reported calling the partners of pregnant women with syphilis to appear at the maternity hospital to be tested and treated, making evident important missed opportunities for timely diagnosis and treatment. In addition, nearly 50\% 
reported difficulty in conversing with the women's partners as a barrier to the effective management of syphilis. Other studies in Brazil have revealed the health professionals' difficulty in addressing the women's partners. In four maternity hospitals in the countryside of the Northeastern state of Pernambuco in 2005, a quite modest proportion of partners of pregnant women with syphilis were successfully brought in for concurrent treatment. ${ }^{25}$ In public maternity hospitals in the Federal District (Midwestern Brazil), in 2009 and 2010, the principal underlying reason for the inadequate management of the pregnant women was the lack of approach or the inadequate management of the partner. ${ }^{26}$ In a large public mother and child hospital in the Southeastern state of São Paulo, no information about the treatment of the sexual partner was available for $73.9 \%$ of the cases of maternal syphilis identified from 2007 to $2014 .^{27}$ In the city of Rio de Janeiro, Southeastern Brazil, a study in 2007 with prenatal care staff working in public health care units also showed the inadequate management of the partners by physicians and nurses, such as sending the test orders or treatment prescriptions via the pregnant woman rather than addressing the partner directly. ${ }^{12}$

Difficulties in treating the sexual partner are associated with the characteristics of the health care services and policies, which historically do not focus on men's health, and with an underestimation of the relevance of social and cultural issues. ${ }^{28}$ The Brazilian $\mathrm{MoH}$ drafted guidelines aimed at the communication with the sexual partners of pregnant women with syphilis, preferably via a letter requesting the partner to appear at the health service. ${ }^{17}$ However, this strategy seems more appropriate for primary care services. In maternities, the greatest challenge in addressing the partner relates to the fact that he is not hospitalized. On the other hand, the male partner is normally present at the maternity hospital while the woman is hospitalized, which represents a good opportunity to address him. Thus, the professional team at the maternity hospital should devise strategies to approach the partner when he visits the woman in the postpartum period. Although such access is sometimes difficult, it is essential to interrupt the transmission chain, provide counseling, and prevent the infection in future pregnancies.

In the current study, the obstetricians failed to counsel the patients on the importance of condom use. Among the nurses, no counseling practice achieved satisfactory rates. The difficulty of the physicians and nurses in counseling on issues related to sexually transmitted diseases (STDs), like transmission routes, health consequences, treatment, and prevention, was also reported by prenatal care staff working in health units in the city of Rio de Janeiro. ${ }^{12}$

Other barriers frequently mentioned by staff for the adequate management of syphilis in the maternities included lack of records of the diagnostic and treatment data on the women's prenatal card, and the women's lack of information about the treatments performed during prenatal care. These difficulties were also reported in a study in the Federal District of Brazil, with a low proportion of postpartum women with syphilis that had prior knowledge of their diagnosis, in addition to incom- plete information on the partner's treatment in the prenatal card and on the patient's chart in the maternity hospitals. ${ }^{26}$ In a Brazilian national study conducted between 2011 and 2012 that analyzed almost 17,000 prenatal cards, $89.1 \%$ had the result of the first "syphilis serology" recorded, and only $41.1 \%$ had the result of the second serology, with regional heterogeneities. ${ }^{29}$

\section{Conclusions}

The present study, which was conducted among obstetricians and nurses working in the public maternity hospitals in the city of Teresina, in the state of Piauí (in the Northeast of Brazil, a region with particularly high CS rates), showed that their knowledge and practices in the management of syphilis in women admitted for childbirth had low levels of agreement with the Brazilian MoH protocols, resulting in missed opportunities for diagnosis, treatment, and counseling of pregnant and postpartum women with syphilis and their partners.

The lack of knowledge about the specific characteristics of the serological tests for the diagnosis of syphilis and about the adequate treatment of the pregnant women and her partners are barriers to the adequate management of the cases of syphilis. Training is considered a strategy with weak results for the implementation of guidelines, but it can increase the familiarity with the guideline contents. In this study, the health professionals had low access to training and manuals about the management of syphilis in pregnancy and the prevention of congenital syphilis. Specific training programs combined with other local strategies for the implementation of guidelines, such as the use of implementation tools, audits and feedback, should emphasize the uptake and adoption of the recommended protocols.

Training the nurses and other strategies to encourage and support their work in the maternity hospital are urgent. These should emphasize the responsibilities and attributions of each group of professionals in the management of syphilis during pregnancy and increase the nurses' involvement in actions related to syphilis control aimed at reducing missed opportunities for diagnosis and providing adequate treatment to the pregnant women and their partners.

There is also a clear need to improve the link between primary care services and maternities, by properly recording on the pregnant women's prenatal card the test results and treatments performed during prenatal care; the integration of the hospital team to approach the male partner at the time of his visit to the postpartum woman also needs to improve. Offering diagnosis, treatment, and adequate counseling for the women and their partners are essential actions to interrupt the syphilis transmission chain. Women's counseling would also reduce the lack of information on tests and treatments during antenatal care, which was reported by the health professionals as a barrier to syphilis control.

Conflict of Interests

The authors have no potential conflict of interests to declare. 


\section{References}

1 Newman L, Kamb M, Hawkes S, et al. Global estimates of syphilis in pregnancy and associated adverse outcomes: analysis of multinational antenatal surveillance data. PLoS Med 2013;10(02): e1001396

2 Kuznik A, Habib AG, Manabe YC, Lamorde M. Estimating the public health burden associated with adverse pregnancy outcomes resulting from syphilis infection across 43 countries in Sub-Saharan Africa. Sex Transm Dis 2015;42(07):369-375

3 Boletim Epidemiológico - Sífilis [Internet]. Brasília (DF): Ministério da Saúde; 2015 [cited in Sep 10, 2016].4(1). Available at: http:// www.aids.gov.br/sites/default/files/anexos/publicacao/2015/ 57978/_p_boletim_sifilis_2015_fechado_pdf_p_18327.pdf

4 Pan American Health Organization. Regional initiative for the elimination of mother-to-child transmission of HIV and congenital syphilis in Latin America and the Caribbean: regional monitoring strategy. 2nd ed. Washington (DC): PAHO; 2012

5 Word Health Organization. Global guidance on criteria and processes for validation: elimination of mother-to-child transmission (EMTCT) of HIV and syphilis. Geneva: WHO; 2014

6 Boletim Epidemiológico - Sífilis [Internet]. Brasília (DF): Ministério da Saúde; 2016 [cited in Sep 10, 2016].5(35). Available at: http://www.aids.gov.br/sites/default/files/anexos/publicacao/ 2016/59209/2016_030_sifilis_publicao2_pdf_51905.pdf

7 Brasil. Ministério da Saúde. Secretaria de Vigilância em Saúde. Programa Nacional de DST e AIDS [Internet]. Protocolo para a prevenção de transmissão vertical de HIV e sífilis: manual de bolso. Brasília (DF): Ministério da Saúde; 2007 [cited in Dec 12, 2016]. Available at: http://bvsms.saude.gov.br/bvs/publicacoes/protocolo_prevencao_transmissao_verticalhivsifilis_manualbolso.pdf

8 Workowski KA, Bolan GA; Centers for Disease Control and Prevention. Sexually transmitted diseases treatment guidelines, 2015. MMWR Recomm Rep 2015;64(RR-03):1-137

9 Brasil. Ministério da Saúde. Secretaria de Vigilância em Saúde. Departamento de DST, AIDS e Hepatites Virais [Internet]. Indicadores e dados básicos da sífilis nos municípios brasileiros. 2016 [cited in May 8, 2017]. Available at: http://indicadoressifilis.aids. gov.br/

10 Brousselle A, Champagne F, Contandriopoulos AP, Hartz Z. Avaliação: conceitos e métodos. Rio de Janeiro: Editora Fiocruz; 2011

11 Brasil. Ministério da Saúde. Secretaria de Atenção à Saúde. Departamento de Atenção Básica [Internet]. Atenção ao pré-natal de baixo risco. Brasília (DF): Ministério da Saúde; 2012 [cited in Sep 10, 2016]. Available at: http://bvsms.saude.gov.br/bvs/publicacoes/cadernos_atencao_basica_32_prenatal.pdf

12 Domingues RMSM, Lauria LdeM, Saraceni V, Leal MdoC. [Treatment of syphilis during pregnancy: knowledge, practices and attitudes of health care professionals involved in antenatal care of the Unified Health System (SUS) in Rio de Janeiro City]. Cien Saude Colet 2013;18(05):1341-1351

13 Brasil. Ministério da Saúde [Internet]. Portaria n. 1.459, de 24 de junho de 2011. Institui, no âmbito do Sistema Único de Saúde SUS - a Rede Cegonha. 2011 [cited in Dec 10, 2016]. Available at: http://www.saude.mt.gov.br/atencao-a-saude/arquivo/3036/ rede-cegonha

14 Gomes SF. Conhecimentos, atitudes e práticas dos médicos e enfermeiros das unidades de saúde da família sobre sífilis em gestantes na cidade do Recife-Pe [dissertation]. Recife: Universidade Federal de Pernambuco; 2013

15 Silva DM, Araújo MA, Silva RM, et al. Knowledge of healthcare professionals regarding the vertical transmission of syphilis in Fortaleza -CE, Brazil. Texto Contexto Enferm 2014;23(02): 278-285

16 Andrade RFV, Lima NBG, Araújo MAL, Silva DMA, Melo SP. Conhecimento dos enfermeiros acerca do manejo da gestante com exame de VDRL reagente. DST J Bras Doenças Sex Transm 2011;23 (04):188-193

17 Comissão Nacional de Incorporação de Tecnologias no SUS [Internet]. Protocolo clínico e diretrizes terapêuticas: infecções sexualmente transmissíveis. Brasília (DF): Ministério da Saúde; 2015 [cited in Sep 10, 2016]. Available at: http://conitec.gov.br/images/ Consultas/Relatorios/2015/Relatorio_PCDT_IST_CP.pdf

18 Comissão Nacional de Incorporação de Tecnologias no SUS [Internet]. Protocolo clínico e diretrizes terapêuticas para a prevenção da transmissão vertical de HIV, sífilis e hepatites virais. Brasília (DF): Ministério da Saúde; 2015 [cited in Sep 10, 2016]. Available at: http://conitec.gov.br/images/Consultas/Relatorios/2015/Relatorio_PCDT_TransmissaoVertical_CP.pdf

19 Brasil [Internet]. Lei n. 7.498, de 25 de junho de 1986. Dispõe sobre a regulamentação do exercício da enfermagem, e dá outras providências. 1986 [cited in Sep 10, 2016]. Available at: http:// www.planalto.gov.br/ccivil_03/leis/L7498.htm

20 Conselho Federal de Enfermagem [Internet]. Resolução COFEN 195/ 1997. Dispõe sobre a solicitação de exames de rotina e complementares por enfermeiro. 1997 [cited in Sep 10, 2016]. Available at: http://www.cofen.gov.br/resoluo-cofen-1951997_4252.html

21 Brasil. Ministério da Saúde. Organização Pan-Americana da Saúde [Internet]. Doenças relacionadas ao trabalho: manual de procedimentos para os serviços de saúde. Brasília (DF): Ministério da Saúde; 2001 [cited in Sep 10, 2016]. Available at: http://bvsms.saude.gov. br/bvs/publicacoes/doencas_relacionadas_trabalho1.pdf

22 Aiken LH, Sloane DM, Klocinski JL. Hospital nurses' occupational exposure to blood: prospective, retrospective, and institutional reports. Am J Public Health 1997;87(01):103-107

23 Brasil. Ministério da Saúde. Secretaria de Vigilância em Saúde. Departamento de DST, Aids e Hepatites Virais [Internet]. Caderno de boas práticas: o uso da penicilina na Atenção Básica para a prevenção da sífilis congênita no Brasil. Brasília (DF): Ministério da Saúde; 2015 [cited in Sep 10, 2016]. Available at: http:// www.aids.gov.br/sites/default/files/anexos/publicacao/2015/ 58373/_p_boas_praticas_2015_final_web_pdf_p_32394.pdf

24 Silveira RP, Pinheiro R. Understanding the need for doctors in innerstate Amazon - Brazil. Rev Bras Educ Med 2014;38(04): 451-459

25 Macêdo VC, Bezerra AFB, Frias PG, Andrade CLT. [Evaluation of measures to prevent vertical transmission of HIV and syphilis in public maternity hospitals in four municipalities in Northeast Brazil]. Cad Saude Publica 2009;25(08):1679-1692

26 Magalhães DMS, Kawaguchi IAL, Dias A, Calderon IdeM. [Maternal and congenital syphilis: a persistent challenge]. Cad Saude Publica 2013;29(06):1109-1120

27 Dallé J, Baumgarten VZ, Ramos MC, et al. Maternal syphilis and accomplishing sexual partner treatment: still a huge gap. Int J STD AIDS 2017;28(09):876-880

28 Oliffe JL, Chabot C, Knight R, Davis W, Bungay V, Shoveller JA. Women on men's sexual health and sexually transmitted infection testing: a gender relations analysis. Sociol Health Illn 2013; 35(01):1-16

29 Domingues RM, Szwarcwald CL, Souza Junior PR, Leal MdoC. Prevalence of syphilis in pregnancy and prenatal syphilis testing in Brazil: birth in Brazil study. Rev Saude Publica 2014;48(05): 766-774 